\title{
Dokument
}

\section{Mulighedernes samfund \\ Uddrag af det officielle regeringsgrundlag}

\section{International sikkerhed og stabilitet}

De globale trusler og udfordringer kræver i stadig stigende grad globale, fælles løsninger. Danmarks sikkerhed varetages bedst gennem et styrket europæisk og transatlantisk samarbejde baseret på fælles værdier og gennem fremme af et internationalt samarbejde, især inden for FN.

Regeringen vil arbejde for, at der med styrkelsen af EU's fælles udenrigs- og sikkerhedspolitik i EU's nye traktat sker en markant styrkelse af EU's globale rolle. Regeringen støtter, at EU i stigende grad påtager sig ansvaret for militære og civile krisestyringsopgaver.

Regeringen vil bidrage til at styrke samarbejdet inden for NATO, som udgør grundlaget for dansk sikkerhed og kernen i et stærkt transatlantisk partnerskab.

Regeringen vil fastholde Danmarks høje internationale engagement i fredsbevarende og fredsskabende indsatser. Vi vil tilstræbe, at Danmarks internationale engagement baseres på brede flertal i Folketinget.

Regeringen vil sikre, at erfaringerne fra de hidtidige danske engage- menter, først og fremmest i Irak og Afghanistan, omsættes i fremadrettede initiativer, der kan styrke samtænkningen af den civile og militære indsats i forbindelse med danske militære indsatser. Særligt fordi Danmark i stigende omfang er militært engageret og yder bistand til genopbygning i meget konfliktramte og farlige områder, er der behov for at styrke samarbejdet mellem civile og militære aktører.

I forhold til det danske engagement i den sydlige del af Afghanistan vil regeringen inden udgangen af 2007 fremlægge en samlet plan for den danske indsats i Helmand provinsen. I løbet af 2008 vil regeringen fremlægge en samlet flerårig Afghanistan Strategi, der rækker frem til 2012. I forhold til Mellemøsten vil regeringen fortsætte Det Arabiske Initiativ. I forhold til den mellemøstlige fredsproces vil Danmark arbejde for, at EU er klar til at yde en markant støtte til regionen, såfremt der sker et gennembrud i forhandlingerne.

I forhold til Irak vil regeringen styrke og konsolidere genopbygningsindsatsen i 2008-2010. Endvi- 
dere vil nærområdeindsatsen blive fortsat i 2008.

I forhold til Balkan og Kaukasus er det vigtigt at sikre en varig og fredelig afklaring af Kosovos status og en stabil, demokratisk udvikling på Balkan og i Kaukasus.

Med henblik på at forberede grundlaget for de politiske drøftelser om et kommende forsvarsforlig, vil regeringen snarest nedsætte en forsvarskommission.

Regeringen vil tage initiativ til at styrke den internationale indsats mod pirateri.

Regeringen vil sikre, at der gennemføres krisestyringsøvelser både nationalt og regionalt, herunder $\mathrm{i}$ samarbejde med internationale partnere.

Regeringen vil fortsat være en aktiv partner i den internationale indsats mod terrorisme og spredning af masseødelæggelsesvåben.

\section{Konkrete initiativer}

Analyse af erfaringerne med samtconkning $i$ Irak og Afghanistan: Regeringen vil anmode Dansk Institut for Internationale Studier om at udarbejde en analyse af de konkrete muligheder for en yderligere styrkelse af samtænkning af den civile og militære indsats i forbindelse med fredsstøttende operationer, baseret på først og fremmest erfaringerne fra de danske engagementer i Irak og Afghanistan.

Fremme samtenkning af civil og mili- ter indsats: Regeringen vil blandt andet med udgangspunkt i en analyse fra Dansk Institut for Internationale Studier gennemføre konkrete foranstaltninger, der kan styrke og sikre gennemførelsen af den militære og civile indsats i fredsstøttende operationer. Hvis situationen i et område vanskeliggør civile organisationers indsats, skal forsvaret kunne bidrage til at løse sådanne opgaver.

Plan for indsats $i$ det sydlige Afghanistan: Regeringen vil inden udgangen af 2007 fremlægge en samlet plan for det danske engagement $\mathrm{i}$ det sydlige Afghanistan, som vil indeholde pejlemærker for den militære indsats inden for den NATO-ledede operation, for den danske udviklingsindsats og for samtænkningsaktiviteter.

Afghanistan-strategi: Regeringen vil i løbet af 2008 fremlægge en samlet Afghanistan Strategi 2008-2012, der i forlængelse af Afghanistan Strategi 2005-2009 fastlægger hovedlinjerne og rammerne for den danske bistand og militære indsats i Afghanistan.

Mellemøsten: Regeringen vil fortsætte Det Arabiske Initiativ og arbejde for, at EU er rede til at yde markant støtte til regionen, hvis der sker et gennembrud i forhandlingerne om Israel/Palæstina-konflikten.

Irak: Regeringen har allerede afsat 100 mio. kr. til nærområdeindsatsen for irakiske flygtninge og internt fordrevne i 2008. Derudover vil regeringen styrke og konsolidere genop- 
bygningsindsatsen i Irak i 2008-2010 ved at afsætte yderligere 100 mio. kr.

Balkan og Kaukasus: Regeringen vil med en øget indsats gennem naboskabsprogrammet og en markant deltagelse i EU's nye Kosovo-mission yde sit bidrag til en stabil, demokratisk udvikling på Balkan og i Kaukasus.

Forsvarskommission: Regeringen vil nedsætte en forsvarskommission til forberedelse af et nyt forsvarsforlig for perioden efter 2009.

Pirateri: Regeringen vil fremsætte initiativer vedrørende bekæmpelse af pirateri, herunder anvendelse af danske flådefartøjer, styrkelse af den internationale ramme for bekæmpelse af pirateri og kapacitetsopbygning i de skrøbelige stater, som piraterne typisk opererer fra.

Beredskabet: Regeringen vil styrke

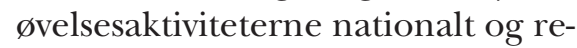
gionalt med henblik på at sikre effektiv koordination af indsatsen ved større hændelser og kriser indenfor og udenfor Danmark.

\section{En mere fri og retfærdig verden}

I de kommende år vil regeringen fortsat have et stærkt fokus på demokrati og menneskerettigheder. Danmark vil styrke indsatsen i EU og FN med henblik på at fremme menneskerettigheder. Det gælder blandt andet debatten om forholdet mellem ytringsfrihed og religionsfrihed.

Danmark vil også tage initiativer i det internationale samarbejde, der sikrer, at bekæmpelse af terrorisme sker i fuld respekt for menneskerettighederne.

Regeringen vil over en årrække sigte på at øge den danske ulandsbistand. Danmark skal fortsat befinde sig blandt de lande, som yder den største bistand. Samtidig vil regeringen yderligere styrke kvaliteten af dansk udviklingsbistand og fastholde et målrettet fokus på kampen mod global fattigdom.

Regeringen vil desuden oprette en særlig klimapulje, der skal bistå ikke mindst de fattige lande i kampen for at begræense og tilpasse sig menneskeskabte klimaforandringer.

Regeringen vil yderligere styrke den danske nærområdeindsats frem $\bmod 2010$.

Regeringen vil nedsætte en Afrika-kommission, der skal udarbejde anbefalinger til, hvordan Danmark bedst kan bidrage til, at Afrika kan opnå fremskridt og udvikling, herunder i forhold til FN's 2015-mål.

Regeringen vil tage initiativer til en særlig international indsats i forhold til FN's 2015-mål nr. 3 om ligestilling og styrkelse af kvinders muligheder.

Regeringen vil udarbejde en strategi for den danske bistand til fremme af demokrati og retsstat og opprioritere den danske indsats i skrøbelige stater, som udgør en særlig udfordring for bistandsindsatsen og arbejdet for frihed, demokrati og menneskerettigheder. 
Og regeringen vil styrke klima- og energiaspekterne i den danske udviklingsbistand.

\section{Konkrete initiativer}

Fremme indsatsen for menneskerettigheder: Regeringen vil tage initiativer $\mathrm{i}$ EU og FN for at fremme indsatsen for menneskerettigheder, herunder i forhold til debatten om forholdet mellem religion og ytringsfrihed. Danmark vil ligeledes tage initiativer i det internationale samarbejde, der sikrer, at bekæmpelse af terrorisme sker i fuld respekt for menneskerettighederne.

$\emptyset$ get bistand der gør en forskel: Det er regeringens sigte over en årrække at øge udviklingsbistanden fra det nuværende niveau på 0,8 pct. af BNI. Den konkrete udmøntning besluttes i forbindelse med de årlige forhandlinger om finansloven og prioriteres inden for de holdbare rammer i regeringens 2015-plan. Regeringen vil fastholde fokus på fattigdomsbekæmpelse og sikre, at den danske bistandsindsats først og fremmest kommer Afrika til gode. Samtidig vil regeringen opbygge en klimapulje, der gradvis skal vokse fra 100 mio. kr. i 2008 til 500 mio. kr. i 2012. Indsatsen skal bistå ikke mindst verdens fattigste lande i kampen for at begrænse og tilpasse sig menneskeskabte klimaforandringer. Regeringen vil samtidig opprioritere arbejdet med at dokumentere resultaterne af den danske bistandsindsats.
En styrket narområdeindsats: Regeringen ønsker at forstærke indsatsen for at hjælpe flygtninge i nærområderne. Frem til 2010 vil regeringen øge nærområdeindsatsen med 100 mio. kr.

Afrika-kommission: Regeringen sigter på, at mindst $2 / 3$ af den bilaterale udviklingsbistand skal gå til Afrika. Med henblik på at sikre den størst mulige effekt af bistanden nedsættes en Afrika-kommission. Kommissionen skal analysere resultaterne af den hidtidige danske udviklingsbistand til Afrika samt udarbejde forslag til en fremtidig strategi, der mest effektivt kan bidrage til at bekæmpe fattigdom og sikre udvikling i Afrika, herunder gennem fremme af FN's 2015-mål. Afrikakommissionen skal aflevere sin betænkning inden sommerferien 2009.

Fremme af FN's 2015 mål nr. 3 om styrkelse af kvinders muligheder: Regeringen vil tage initiativer til en særlig international indsats for fremme af FN's 2015 mål nr. 3 om ligestilling og styrkelse af kvinders muligheder. Som led i prioriteringen af den danske udviklingsbistand vil bistanden til fremme af kvinders rettigheder og muligheder blive fordoblet fra 2008 frem mod 2010.

Demokrati og retssamfund $i$ udviklingsbistanden: Regeringen vil i 2008 udarbejde en strategi for den danske bistandsindsats vedrørende demokrati og retssamfund i udviklingslandene. 


\section{DOKUMENT}

Skrøbelige stater: Regeringen vil i 2008 udarbejde vejledende principper for en styrket og mere sammenhængende dansk udviklingsindsats i skrøbelige stater.

\section{Danmark i hjertet af Europa}

EU er den centrale ramme for samarbejde i Europa. Det er i Danmarks interesse, at Europas fælles udfordringer og problemer løses i et demokratisk, samarbejdende og stærkt EU med ens regler for alle.

Det er særdeles positivt, at der er opnået enighed om en ny traktat, som skal ratificeres i løbet af 2008 . Traktaten sikrer et mere demokratisk, beslutningsdygtigt og effektivt EU, og styrker EU's internationale rolle. Med traktaten er den nødvendige ramme for det fremtidige EUsamarbejde tilvejebragt.

Regeringen er meget tilfreds med, at den ny traktat vil forbedre mulighederne for at løse vigtige internationale problemer som klimaforandringer, organiseret kriminalitet og terrorisme.

Med aftalen om den ny traktat er der for en rum tid sat punktum for drøftelserne om rammerne for EU. Det betyder, at der kan sættes fokus på indhold og resultater af den konkrete politik, der bliver ført i EU.

Regeringen lægger stor vægt på, at traktatens nye muligheder udnyttes til målrettet at skabe resultater og præge EU's udvikling i dansk retning. Det gælder blandt andet øget vækst og beskæftigelse, en socialt balanceret udvikling, en ambitiøs klima- og energipolitik, en fortsat stærk miljøprofil, vidtgående reformer af landbrugspolitikken og et højt niveau for dyrevelfærd. Desuden skal EU påtage sig et større globalt ansvar og EU skal styrke indsatsen mod terror og grænseoverskridende kriminalitet.

Regeringen ønsker herudover at videreføre en ansvarlig udvidelsespolitik, ligesom indsatsen over for EU's nabolande skal styrkes for at bidrage til reformer og modernisering i disse lande.

Regeringen finder, at Danmarks interesser er bedst tjent ved, at vi er fuldt og helt med i EUsamarbejdet. Kun på den måde kan vi fuldt ud drage nytte af EU-medlemskabet og samtidig solidarisk yde vores bidrag til fællesskabet.

Den ny traktat berører i sig selv ikke direkte de danske forbehold, som videreføres i traktaten. Traktaten åbner dog mulighed for, at Danmark selv - efter en folkeafstemning - kan beslutte at deltage i samarbejdet om retlige og indre anliggender fra sag til sag.

Med den nye traktat vil Danmark stå udenfor en større del af samarbejdet. Regeringen finder, at tiden er løbet fra forbeholdene fra 1993, som blev til i en anden tid og under særlige omstændigheder.

Regeringen ønsker derfor, at vælgerne ved folkeafstemning får lejlighed til at tage stilling til forbeholdene. 
Regeringen lægger stor vægt på, at der også i fremtiden er bred opbakning bag en positiv linje i dansk Europapolitik.

Regeringen vil derfor søge at indgå en fornyet politisk aftale om grundlaget for dansk Europapolitik med et bredt udsnit af Folketingets partier.

En sådan aftale skal bidrage til at give dansk Europapolitik en stærk platform for en fortsat aktiv, resultatorienteret og offensiv dansk Europapolitik i de kommende år.

\section{Konkrete initiativer}

EU's globale ansvar: Regeringen vil arbejde for, at den større internationale synlighed og gennemslagskraft, som EU får med den ny traktat, udnyttes bedst muligt. EU skal påtage sig et større globalt ansvar og bidrage til at styrke frihed, demokrati, menneskerettigheder og den internationale retsorden. EU skal bekæmpe international terrorisme og bidrage til at udrydde nød og fattigdom, herunder en særlig indsats for yderligere at uddybe samarbejdet med Afrika.

En ambitiøs klima- og energipolitik: Regeringen vil bruge EU til at fremme en ambitiøs klimapolitik, som kan bane vejen for en fremtidig global klimaaftale. EU har allerede udvist lederskab med beslutningen om at begrænse drivhusgasudledningerne med 30 pct. i 2020 som led i en global aftale. Nu gælder det om at udvikle en fælles EU-energipolitik med en væsentlig udbygning af den vedvarende energi, og vi skal have skabt et effektivt, europæisk energimarked.

\section{Bekcmpelse af granseoverskridende} trusler: Regeringen vil arbejde for, at EU-samarbejdet skaber tryghed for borgerne ved at bekæmpe de trusler, som eksempelvis terror og grænseoverskridende kriminalitet udgør. Regeringen ser også gerne, at EU spiller en større rolle i indsatsen for at løse flygtningeproblemer og bekæmpelsen af ulovlig indvandring.

Vekst og beskaftigelse: Regeringen vil arbejde for at styrke EU som ramme for vækst og beskæftigelse i en stadig mere globaliseret verden. EU skal gå forrest i de internationale bestræbelser for at fjerne handelsbarrierer og fremme et multilateralt handelssystem. Samtidig skal vi styrke og videreudvikle det indre marked og fremtidssikre EU's konkurrenceevne gennem økonomiske reformer og en øget satsning på forskning, udvikling, innovation og uddannelse.

Styrket indre marked til gavn for dansk vakst og forbrugerne: Regeringen vil arbejde for, at EU stadig udbygger og forbedrer det indre marked til gavn for danske virksomheder og borgere. Regeringen vil arbejde for en bedre kontrol med varer fra lande uden for EU, blandt andet gennem bedre koordination af medlemslandenes indsats.

Et socialt baredygtigt EU: EU-samarbejdet skal bygge på et socialt bære- 


\section{DOKUMENT}

dygtigt grundlag og understøtte de europæiske velfærdssamfund. Indretningen af velfærdssamfundet bør fortsat være en national opgave, men EU-samarbejdet skal også indeholde en social dimension.

Et højt beskyttelsesniveau: Regeringen vil arbejde for at forbedre miljøkvaliteten og løfte beskyttelsesniveauet i nuværende og nye medlemslande. Og for, at EU's regelsæt baseres på et højt niveau for fødevaresikkerhed, forbrugerbeskyttelse og dyrevelfærd.

Reformer af landbrugspolitikken: Regeringen ønsker en afvikling af EU's landbrugsstøtte. Regeringen vil derfor udarbejde en strategi for, hvordan Danmark aktivt kan arbejde for en afvikling af EU's landbrugsstøtte. Regeringen vil arbejde for vidtgående reformer, herunder en øget markedsorientering og en mere handelsliberal landbrugspolitik.

En ansvarlig og konsekvent udvidelsespolitik: EU's udvidelsesproces har skabt frihed, demokrati og økonomisk udvikling i de nye EU-lande. Perspektivet om medlemskab vil også i fremtiden være et vigtigt element i EU's politik. Regeringen lægger vægt på en konsekvent og ansvarlig linje i udvidelsespolitikken med fokus på hvert enkelt kandidatlands opfyldelse af Københavnskriterierne, ligesom EU også selv være parat til at optage nye lande. Udvidelsesprocessen med Tyrkiet fortsætter inden for den aftalte ramme. EU skal fortsat påtage sig sit ansvar over for landene på Balkan. Perspektivet om EU-medlemskab skal være troværdigt selvom medlemskab først kan komme på tale på længere sigt.

Tat samarbejde med EU's nabolande: EU skal målrettet understøtte EU's nabolandes ønske om et tættere samarbejde gennem en sammenhængende og balanceret nabopolitik, herunder med vægt på de nye naboer mod øst. Nabopolitikken skal medvirke til at fremme reformprocessen i landene og derved bane vejen for deres modernisering og gradvise integration med det indre marked i EU. Danmark vil fortsat gennem sin egen politik over for nabolandene bidrage til reformprocessen og yderligere udvikling.

Ny politisk aftale om Europapolitikken: Regeringen ønsker at videreføre den brede enighed om Europapolitikken i form af en ny politisk aftale, der tager afsæt i de muligheder, som den nye traktat giver.

Afstemning om forbeholdene: Regeringen ønsker, at vælgerne ved folkeafstemning får lejlighed til at tage stilling til forbeholdene.

November 2007 